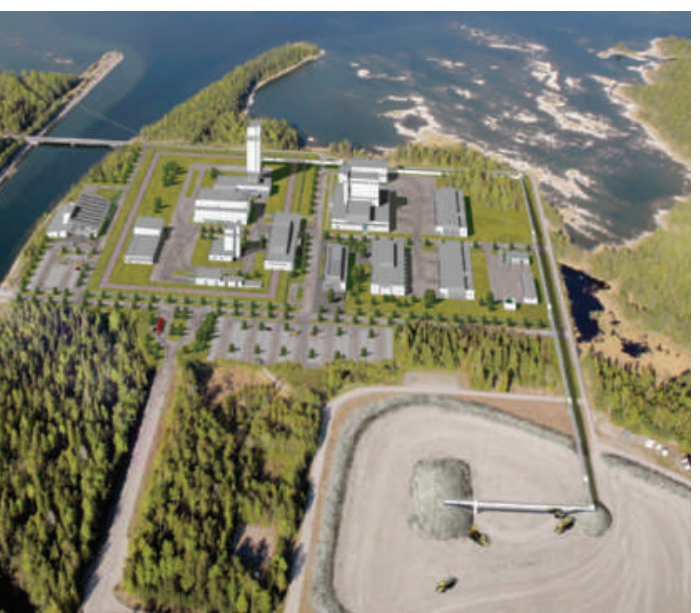

A mock-up of Sweden's nuclear-waste store.

\section{Sweden finally picks nuclear-waste burial site}

After almost two decades of deliberation, Sweden last week announced a final destination for its nuclear waste. The community of Forsmark, around 100 kilometres north of Stockholm, will play host to a long-term storage facility for some 12,000 tonnes of spent nuclear fuel.

The fuel will be housed 500 metres underground in copper canisters buried in bentonite clay. Geologists believe that the combination will keep the fuel geologically stable for up to 100,000 years - the time it will take for the radioactive elements inside to decay to safe levels.

Svensk Kärnbränslehantering, the company tasked with nuclear-waste disposal, hopes to have the SEK12.5-billion (US\$1.6-billion) facility fully operational by 2023 .

\section{German science secures historic windfall}

German universities and research organizations will receive an $€ 18$-billion (US\$25-billion) windfall over the next decade, after Chancellor Angela Merkel and the prime ministers of the country's 16 states agreed on 4 June to finance the package.

In April, the weak economy had made some states waver in their intention to contribute to the proposed programmes, and Peer Steinbrück, Germany's finance minister, had suggested that a final decision might need to be postponed until after September's federal parliamentary elections.

The funding extends three initiatives intended to strengthen research budgets, encourage university competition and prepare for a rise in student numbers - which together account for the largest single investment in science and higher education in Germany's post-war history.

For a longer version of this story, see http://tinyurl.com/1768c6.

\section{Rotavirus vaccines win global recommendation}

The World Health Organization (WHO) has recommended that health authorities in all nations routinely vaccinate young children against rotavirus, which causes 2 million hospitalizations and 500,000 deaths from severe diarrhoeal dehydration every year.

Rotavirus vaccines are already recommended for use in the Americas and Europe. But more than $85 \%$ of deaths caused by rotavirus occur in developing countries in Asia and Africa, says the WHO.

The recommendation was made by the WHO's Strategic Advisory Group of Experts, which reviewed a clinical trial of GlaxoSmithKline's Rotarix vaccine in South Africa and Malawi that cut the occurrence of severe diarrhoeal episodes. RotaTeq, a rotavirus vaccine developed by Merck, is being tested in clinical trials in Japan, India, Mali, Ghana, Kenya, Bangladesh and Vietnam.

\section{Californian universities hit by state's budget woes}

Californian universities are reeling from unprecedented budget cuts triggered by the state's deficit of more than $\$ 24$ billion.

The ten-campus University of California expects to see US\$800 million cut from the $\$ 3.2$ billion in state funds it was due to receive over the 2009-10 operating year. And the 23-campus California State
University system, which mainly provides undergraduate degrees, anticipates that at least $\$ 580$ million will be sliced from its \$2.7-billion state award.

University of California executives met on 3 June to discuss how they would cope with the cuts in preparation for what is expected to be a turbulent summer. The budgetary axe began taking its toll after voters in last month's state-wide election rejected a series of proposals designed to ease California's deficit.

For a longer version of this story, see http://tinyurl.com/mwaadb.

\section{Legal accord eases path to Europe's research facilities}

A standard legal framework governing all pan-European research facilities should make it easier for nations to develop large shared projects, European Union (EU) research ministers said after reaching agreement on the scheme on 29 May.

The framework, proposed last year by the European Commission, means that countries will no longer have to debate afresh - under a hotchpotch of national and EU laws - the structure and governance of each European Research Infrastructure (ERI), as collaborations are called. Future ERIs - such as the European Spallation Source, a neutronscience facility (see Nature 459, 626; 2009) - will be granted the status of an international organization, and exempted from VAT (value added tax) and excise duty.

"It will bring down barriers to investments in science and research," said Czech education minister Miroslava Kopicová, who chaired the Competitiveness Council meeting in Brussels.

\title{
Submersible plumbs the depths
}

For the first time in more than a decade, scientists have penetrated the deepest parts of the Pacific Ocean. The deep-sea remotely operated vehicle Nereus dived 10,902 metres to the bottom of the Challenger Deep in the Mariana Trench on 31 May

- the first visit since that of Japan's Kaiko submersible in 1998.

Nereus, built by researchers from the Woods Hole Oceanographic Institution in Massachusetts (see Nature 437, 612-613; 2005), was dropped from the research vessel Kilo Moana, and spent ten hours on the bottom gathering samples and sending back images (pictured, inset).

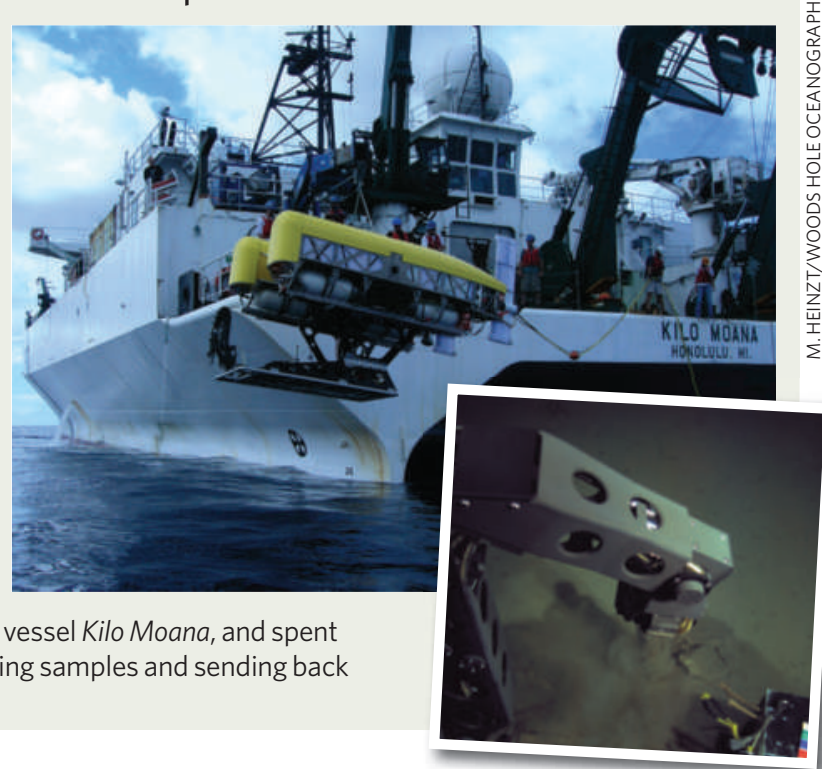

